\title{
VIOLÊNCIAS E SUBJETIVIDADES: O INDIVÍDUO CONTEMPORÂNEO
}

\author{
Angela Maria Pires Caniato \\ Universidade Estadual de Maringá, Maringá, Brasil
}

\begin{abstract}
RESUMO: O estudo da relação violências e subjetividades é bastante complexo, tanto em função das muitas acepções da violência na sociedade quanto pelas suas especificidades e diferentes implicações relacionais na construção das individualidades. Entendi a privação como sendo a acepção comum a todos os processos de violência e identifiquei a intervenção dos mecanismos cruéis da violência de Estado sob o Capital como um importante articulador da violência na sociedade contemporânea. A violência social, enquanto violência simbólica, é apreendida nesse estudo com a ajuda da Teoria Crítica, de Theodor Adorno, e da Psicanálise, e quando internalizada pelas subjetividades nos processos de identificação projetiva e introjetiva. São examinadas as técnicas de encobrimento e de banalização da violência na sociedade assim como aquelas que produzem a estandardização e conformação dos indivíduos com a conseqüente deteriorização dos diferentes processos psíquicos.
\end{abstract}

PALAVRAS-CHAVE: Violência social e violência de Estado; Psicanálise; violência simbólica internalizada; banalização da violência; pseudo-individuação.

\section{VIOLENCES AND SUBJECTIVITIES: THE CONTEMPORARY INDIVIDUAL}

ABSTRACT: The relationship between violence and subjectivities is a highly complex issue due to the several meanings given by society and to its specificities and different relational implications in an individual's construction. Privation is the most commonly accepted meaning in all processes of violence and the intervention of violent mechanisms practiced by the State within the capitalist regime as one of the main articulator of violence within contemporary society. Social violence, as symbolical violence, is analyzed according to Adorno's Critical Theory and to Psychoanalysis while internalized by the subjects within the projection and introjection processes. Techniques of covering up and trivializing violence in society are investigated as much as those that lead towards standardization and conformity of individuals with the subsequent deterioration of different psychic processes.

KEYWORDS: Social violence and violence by state; Psychoanalysis; internalized symbolic violence; trivialization of violence; pseudo-individualization.

Desde que atendi a ex-presos políticos que haviam sofrido torturas nos quartéis da ditadura militar de 1964, venho tematizando sobre a violência. É um conceito bastante complexo, atribuindo-se a ele muitas acepções e qualificações. Seja qual for a sua origem, forma de expressão e categorização há, em sua essencialidade, o sentido de privação (Odália, 1983).

Estou atenta para discernir das demais expressões da violência na sociedade o que é violência de Estado violação dos direitos humanos. A Red de Informática de Instituciones de Derechos Humanos de Chile ([FASIC], 1991) assim define a violação dos direitos humanos:

aqueles delitos que atentam contra os direitos fundamentais do homem, enquanto membro da humanidade, que se encontram definidos na Declaração Universal dos Direitos Humanos e que são realiza- dos pelo Estado - direta, indiretamente ou por omissão - ao amparo de seu poder único. Desta maneira, o Estado anula sua finalidade essencial e provoca a inexistência do estado de direito. (p. 13).

A violação de direitos humanos é exercida por um funcionário público, por pessoa ou grupo de pessoas, que contam com a proteção, consentimento ou aquiescência do Estado diante de uma presumida ameaça à sociedade e em nome de uma suposta proteção aos cidadãos. A atrocidade da violência de Estado fica camuflada porque certos Estados se outorgam a prerrogativa de manter seus atos deletérios sob segredo de estado, não permitindo o julgamento público e a condenação dos agentes a seu serviço que cometem torturas, repressão policial militar, assassinatos e desaparecem com pessoas. As guerras são legitimadas pelo Estado como estratégia de 
poder de sociedades ditas "democráticas" contra grupos invasores, aventureiros, saqueadores ou delinqüentes que, atualmente, são identificados sob a categoria de acusação - "terrorista".

Estamos assistindo a verdadeiras ações genocidas dos governos monopolistas e autoritários da sociedade globalizada atual. Espalha-se, pelo planeta, a permanência do holocausto, tal como analisa Bauman (1998) em sua obra Modernidade e holocausto. Embora justificadas como necessárias à manutenção da soberania aviltante de grandes potências econômicas e, em nome da defesa da democracia, tais violências, de fato, são utilizadas para encobrir a opressão de países hegemônicos sobre as populações alienígenas e/ou pauperizadas, e para sustentar a avidez de lucro da economia capitalista. Não há dúvida de que tais ações beligerantes tornam vulneráveis os povos e as populações já dizimados pela pobreza. É a ganância por mais lucro que produz a disseminação das guerras. Elas sustentam a riqueza de alguns estados soberanos que têm na produção e venda de armamentos bélicos, sua principal fonte de renda. A violência de Estado e a globalização atual se imbricam, portanto, na manutenção do poderio econômico de alguns países ricos.

Em relação à violência social - diferente da violência de Estado - as privações se exprimem em diferentes âmbitos da vida em sociedade e nas instituições da cultura. Em nível da estrutura econômica de produção, o uso perverso da tecnologia no mundo do trabalho, assim como as mudanças atuais na organização do processo produtivo (toyotismo), passaram a exigir o "homem flexível" (Sennett, 2001). Tais mudanças respondem às novas exigências do neoliberalismo em relação à supressão prioritária das demandas de consumo e não mais na acumulação de estoque de mercadorias. Os trabalhadores sofrem as exigências de performances diferenciadas e são conduzidos à exaustão, ludibriados pelos louvores enganosos do "trabalho cooperativo" (Barbarini, 2001). Em nível estrutural da produção econômica enquadramse, portanto, importantes privações impostas à classe trabalhadora. A violência assume diferentes expressões, mais ou menos mutiladoras dos indivíduos. A diminuição dos postos de trabalho são estratégias do processo produtivo para a garantia de mais lucro. $\mathrm{O}$ fato implica, cada vez mais, o aumento da precariedade das condições de sobrevivência dos trabalhadores devido ao desemprego estrutural. Ao mesmo tempo em que o sistema executa a superexploração daqueles que trabalham -"homem flexível"-, expulsa um número cada vez maior de indivíduos do sistema produtivo, lançando na miséria esse contingente crescente de homens (Martin \& Schumann, 1999). O trabalho, principal forma de inserção ativa do homem na sociedade (Leontiév, 1978), vem se transformando em exposição de uns ao sofrimento (Dejours, 2000) e de muitos à morte (Ramonet, 2003).
Não cabe, nos limites deste artigo, abordar, sob a ordenação cultural contemporânea, as múltiplas formas do desdobramento da violência no cotidiano da vida em outras instituições sociais e nas relações entre os indivíduos. É inconteste que o principal organizador das relações sociais na atualidade é a mídia, que tem profundo poder de penetração nas diferentes camadas da sociedade. A televisão, em especial, tem ampla difusão junto à maioria da população, constituindo-se no principal veículo da ideologia, expressão privilegiada da violência simbólica. É a ideologia que sustenta a hegemonia da classe dominante: a burguesia. Privilegiei a análise da violência simbólica que é orquestrada pela indústria cultural para gerir a construção do "tipo psicológico ordinário" (Costa, 1986), isto é, aquela forma de individuação e de vínculos sociais que mantém o status quo. Os modelos identificatórios são construídos e difundidos pela mídia para a manipulação /padronização dos indivíduos, o que facilita manter a todos sob controle social.

O referencial da teoria crítica de Theodor W. Adorno serviu de suporte teórico-metodológico para a análise desse processo psicossocial, já que permite, aguçadamente, examinar os caminhos da violência simbólica nas relações sociais e os processos identificatórios por meio dos quais essa violência é internalizada pelas subjetividades. O conceito de indústria cultural explicita e permite identificar as estratégias ideológicas de dominação sobre as relações sociais que vem sendo utilizadas para conquistar a adesão dos indivíduos ao consumismo (Mariotti, 2002) a fim de potencializar a ganância do lucro capitalista.

A Psicanálise, por outro lado, permite acompanhar a internalização dessas estratégias sociais de captura dos indivíduos e analisar os efeitos disruptivos da internalização dessas ideologias nas subjetividades. O exame dessas identificações projetivas-introjetivas revela as fantasias destrutivas inconscientes que sustentam as mentiras mais ou menos manifestas. A construção social e a difusão dessas fantasias, entre os indivíduos, servem para impedir o desenvolvimento do pensamento reflexivo. Os indivíduos são mantidos em funcionamento mental regressivo, atados, simbioticamente, às leis da sociedade de consumo. São cúmplices, conseqüentemente, ainda que inconscientemente do processo social que os violenta. Essa estratégia social de manipulação e de controle permite driblar a possibilidade de oposição e resistência dos homens às exigências do autoritarismo que atravessa as sociedades atuais, assim consideradas como democráticas.

Não há dúvida de que tais maquinações vêm substituindo os laços afetivos e de acolhimento exigidos pelo desenvolvimento das estruturas psíquicas superiores (da consciência reflexiva) e dos processos de individuação/ diferenciação entre os indivíduos. Mais: pervertem a qualidade das relações afetivas entre eles. Em especial, a 
dialética presente, nessa relação, fica melhor bem esclarecida e compreendida se pensarmos por dentro do processo de padronização, construído pela imposição de modelos identificatórios estandardizadores/ conformadores. Esses modelos são internalizados nas identificações projetivas-introjetivas e acolhidas pelos indivíduos como se fossem originadas dentro deles mesmos. A Psicanálise, portanto, oferece o suporte teórico para a apreensão e compreensão da relação indivíduo cultura, para o desvelamento dessas distorções e para as implicações da exposição regressiva dos indivíduos a essas formas mutiladoras de ação da cultura.

$\mathrm{Na}$ análise do processo de internalização da violência social, torna-se imprescindível o respaldo do célebre texto de Freud (1930/1981a) - El malestar en la cultura - no qual o autor fornece os parâmetros para examinar a internalização dessa violência. É necessário, sob culturas autoritárias, identificar e acompanhar os processos de culpabilização e autopunição gerados nas subjetividades (sentimento inconsciente de culpabilidade). Nessas sociedades, há a permissão para que uma minoria possa agredir, enquanto a maioria dos indivíduos é obrigada a conter as suas agressividades, vivendo sob a "mais-repressão". Há uma proibição para reagir aos desagravos sofridos. O indivíduo tem de conter sua agressividade protetora (ligada à preservação da vida) e submeter-se à violência daqueles a quem a sociedade permitiu violentá-lo.

Pergunta-se: o que vem a ser a vociferação das denominadas políticas públicas de inclusão social senão uma possante estratégia de controle social? O Estado que a advoga está cada vez mais inoperante e omisso na sociedade sob domínio do lucro. $\mathrm{O}$ apelo à cumplicidade dos indivíduos a um suposto acesso aos bens produzidos socialmente é um discurso condizente com a adesão desses indivíduos e grupos às regras da sociedade atual. Essas regras, de fato, produzem a conformação da maioria dos indivíduos com o movimento extensivo e multifacetado da violência da exclusão social, de fato existente. Na sociedade em que prevalece a lógica do dinheiro e do lucro - onde reina o Senhor Capital - inexiste qualquer preocupação com os valores humanos. Conseqüentemente, só se pode entender tal manipulação das mentes como uma falácia que encobre a permanência das desigualdades no suprimento das reais e diferentes exigências dos indivíduos para continuarem a vida. Esse discurso é uma poderosa arma, uma estratégia de poder, ideologicamente normatizadora, para a contenção das populações pauperizadas.

A prevalência do arbítrio do processo econômico faz eclodir e disseminar a violência em todos os âmbitos da vida social. A violência ressoa e amplifica sua força ao encontrar indivíduos inertes, pois se tornam cúmplices desse processo violentador que já os destruiu. Hanna Arendt (1973) diz: homens sozinhos, sem outros que os apóiem, nunca têm suficiente poder para usar a violência com sucesso. . . Freqüentemente se diz que impotência gera violência e, psicologicamente, isto é. . . Mas politicamente a questão é que a perda de poder traz a tentação de substituí-lo pela violência ... a própria violência resulta em impotência. . . Estou . . . inclinada a pensar que a maior parte da atual glorificação da violência seja causada por uma profunda frustração da faculdade de agir no mundo moderno. (p. 128-153).

A proliferação das guerras responde a essa incapacidade de o indivíduo, tornado "máscara mortuária", frear a fetichização da mercadoria e de seu domínio universal de consumo. O indivíduo, capturado, está submerso e não consegue sair dessa relação de impotência violentado/violentador. Mais ainda: paradoxalmente, esse indivíduo está aclamado como "herói" sob essa condição de barbárie para, ainda, tentar produzir a sua sobrevivência e a daqueles que estão sob sua dependência. Como conseguir tal façanha se nem sempre ele identifica quem são e para onde estão lhe levando os seus reais inimigos?

As relações violentas que caracterizam a vida em sociedade, atualizam-se de forma disfarçada por meio da poderosa tecnologia da indústria cultural. Exprimem o disfarce cínico da violência que penetra profundamente no âmago da vida subjetiva e de relações dos indivíduos. Homens, mulheres e crianças, em diferentes partes do globo terrestre, são empurrados para a fragilização no estado de desamparo, sem conseguirem se organizar em ações de sujeitos participantes para a constituição de um poder político verdadeiramente protetor e voltado para o bem de todos.

Devemos fazer, talvez, um ato de fé ou crer no potencial sujeito do indivíduo. Nesse potencial pode estar sendo gestada a sua emancipação ou diferenciação devido ao surgimento de formas criadoras e acolhedoras de relações entre os indivíduos, sob as quais se torne possível a atualização de ideais em um "mundo da vida". Em alguns indivíduos e grupos humanos já germinam perspectivas de mudanças, com a tendência, talvez, para vínculos mais continentes e solidários, que possam não só expressar um poder de resistência contra a destruição da humanidade mas também que possam ser suficientemente emancipatórios para reconduzir os homens à sua condição de sujeitos da cultura (Adorno, 1995).

Nem todas as questões levantadas neste texto estão exaustivamente expostas. Devo informar que, muitas dessas situações aqui identificadas, quer sejam aquelas vinculadas à questão das violências na sociedade contemporânea, quer sejam as relacionadas à construção das subjetividades atuais, já foram por mim estudadas ou orientadas em pesquisas de Iniciação Científica e Pós-Graduação. Não caberia retomá-las nos limites deste artigo. Outros temas aqui levantados devem ser aprofundados 
em trabalhos posteriores. Esse é o limite de pesquisa de um objeto complexo como é a questão das relações recíprocas entre as violências e as subjetividades.

\section{A perspectiva psicopolítica frankfurtiana no estudo das subjetividades}

A abordagem psicopolítica para aproximar a relação violência e subjetividade, neste trabalho, vem sendo construída por mim no decorrer da formação em Psicanálise, iniciada na década de 60 do século passado, tendo sua configuração redefinida, posteriormente, com os estudos da teoria crítica, de Theodor Adorno. Por situações inusitadas vivenciadas por mim a partir de 1985, em processo psicoterápico com ex-presos políticos da Ditadura Militar de 1964, adentrei a abordagem psicopolítica frankfurtiana. O princípio da Teoria Crítica para a compreensão do indivíduo considera a especificidade das leis culturais que, em determinado momento histórico, organiza as relações entre os indivíduos e, com o referencial da Psicanálise, analisa o suporte subjetivo das ações individuais e coletivas.

Exigiam-se outros parâmetros teórico-metodológicos para a busca de uma interpretação mais verdadeira do horror vivido pelos meus clientes que sofreram torturas nas prisões militares. Eu desconhecia o que era ser preso e receber tortura como técnica para obter confissões. Não encontrei, na literatura psicanalítica existente nessa época no Brasil, qualquer produção sobre o que era o terrorhorror de ser torturado. Os clientes clamavam, com os seus sofrimentos, por um acolhimento correlato às vivências remanescentes de terem sido torturados. Mereciam respeito pela resistência de suas militâncias políticas e pelo sofrimento em consequiência das punições que receberam. Não cabia uma interpretação intimista culpabilizadora que se assentasse, apenas, em seus mundos internos, negando a realidade externa de terem ficado presos em quartéis do Exército Brasileiro nos quais foram seviciados por militares-torturadores.

Embora já fossem passados mais de vinte anos desde que foram dramaticamente violentados nas prisões do Estado Militar, ainda reverberava dentro deles o horror vivido no âmago de suas vidas. O "torturador internalizado" mantivera-os, ardilosamente, subordinados a seus arbítrios, contaminando, por sua violência e pelo sofrimento que lhes causava, seus contatos interpessoais e a convivência com o coletivo social. Essa vivência projetiva perseguiu-os durante o longo período desde que saíram da prisão (década de 70) e reapareceu no momento em que vieram procurar ajuda psicoterápica, já nos fins da década de 80, quando a Ditadura já havia sido suspensa. Viviam acuados e assustados como se ainda estivessem na militância política clandestina, passíveis de serem presos e novamente torturados. Tal vivência reaparecia não só junto aos amigos fiéis, mas também na relação transferencial junto a mim: "você já esta querendo saber demais" (sic). Essa vivência orientou por várias vezes o seu afastamento do processo terapêutico e conduziu a quebra de antigos vínculos afetivos com amigos que, sob essa circunstância, eram identificados como seus malfeitores.

Esse foi o momento crucial desencadeador para que eu me integrasse na perspectiva psicopolítica para a busca do entendimento do horror vivido por eles, com quem tive relação psicoterápica e que vieram a se transformar em sujeitos da minha tese de doutorado - "A história negada. Violência e cidadania sob um enfoque psicopolítico" (Caniato, 1995).

Os limites de conhecimento de minha formação psicanalítica até então me impediam dialogar com suas vivências anteriores de tortura na prisão. Essas vivências emergiam como um vômito e que eram eivadas de muito horror. Perplexa e passiva eu captava transferencialmente esse episódio, inusitado para mim, e vivia esses momentos sob muita angústia. Felizmente, esse meu sofrimento foi libertador e serviu de alerta para a procura de novas formas para entender e lidar com as vivências desses indivíduos. Essas vivências passaram a ser compreendidas sob o enfoque da natureza psicossocial. Tenho clareza de que enfrentei o desafio sem me culpabilizar, pois fui à luta, saindo para congressos na América Latina à procura de bibliografia na Psicanálise que abordasse a questão da tortura, uma vez que não a encontrara na produção dos psicanalistas brasileiros. Encontrei, no exterior, bastante produção psicanalítica, e sou muito grata a Elizabeth Lira no Chile, René Kaës e Diana Kordon, na Argentina, e Marcelo Viñar, no Uruguai, entre outros. A minha abordagem psicanalítica da agressividade até aquela época era parcial e centrada nas pulsões destrutivas do inconsciente psíquico, apenas. Não era muito diferente do que ainda hoje persiste na formação da maioria dos psicanalistas, que continuam tratando o mundo psíquico como se fora uma mônada e sob uma "visão de avestruz". Desconsideram as internalizações da violência (mundo externo) como integrante dos processos identificatórios dos indivíduos (Caniato, 1999b).

À apreensão psicanalítica, que passou a nortear meu trabalho clínico, agregou e impôs-se como evidência a exigência de integrar a compreensão da especificidade da violência da prisão e da crueldade da tortura sofridas por esses indivíduos no passado (Ulloa, 1999, 2000). Eles tinham em comum um grande sofrimento, fundado em reminiscências destrutivas que, ainda, se mantinham atuantes nas suas relações consigo mesmos e com os seus pares, embora estivessem mais ou menos reprimidas. Em suas vivências transferenciais, orientavam-se pelo horror vivido nas torturas sofridas que não podiam ser 
entendidas, como acidentes traumáticos de origem interna, apenas. $\mathrm{O}$ fato de terem sido presos e submetidos às diferentes estratégias de tortura tem a sua especifidade entre os traumas humanos. A penetrabilidade corporalsensorial do sofrimento físico e psíquico imprime profundas marcas inconscientes na vida mental dos torturados, mesmo porque são experiências vividas no desamparo do isolamento silencioso das prisões militares e sob a concretude do imprevisto impensável de diferentes técnicas e artefatos de que dispõem os torturadores: está em suas mãos a possibilidade de o preso permanecer vivo ou a iminência de sua morte.

A psicóloga Cecília Coimbra (2003), também expresa política da Ditadura de 1964, em seu texto Gênero, militância, tortura, relata contingências dramáticas vividas por ela sob a prisão-tortura. Afirma:

Falar daqueles três meses e meio em que fiquei detida incomunicável sem ao menos, um único banho de sol ou qualquer outro tipo de exercício é falar de uma viagem aos infernos, dos suplícios físicos e psíquicos, dos sentimentos de desamparo, solidão, medopânico, abandono, desespero; é falar da 'separação entre corpo e mente'. (p. 19).

A tortura transforma nosso corpo - aquilo que temos de mais íntimo - em nosso torturador, aliado aos miseráveis que nos torturam. Esta é a monstruosa subversão pretendida pela tortura. Ela nos parte ao meio. . . O corpo na tortura nos aprisiona . . . ele se volta contra nós, na medida em que exige de nós uma capitulação. . . O corpo que é torturado, nos tortura, exigindo de nós que o libertemos da tortura, a qualquer preço. Ele se torna, portanto . . . o porta-voz dos torturadores, aliado a estes na sinistra tarefa de nos anular . . . transformando-nos em objeto. É justamente essa a terrível situação da tortura: através da dor, da humilhação e da degradação tentam transformarnos em coisa, em objeto. Resistir a isso é um enorme e gigantesco esforço para não perdermos a lucidez, para 'não permitir que o torturador penetre [em nossa] alma, [em nosso] espírito, [em nossa] inteligência'. (Chaui, 1993, p. 9-34).

Acolho ainda o que um psiquiatra, também ex-preso político da ditadura no Chile - exilado e atualmente radicado na Alemanha - arriscou a falar sobre a angústia que vivera sob o terror no período em que foi preso político.

O idioma habitual não contava com expressões para fazer comunicável a experiência do terror, não havia significados para a intensa angústia do medo crônico por razões externas e inquestionáveis; somente se sabia calar frente a vergonha por ofensas à intimidade, concebida até então como inviolável; faltavam estruturas de comunicação para a dor da tortura que se auto-perpetua no vitimado; era reduzido ao âmbito expressivo para manifestar a insegurança de quem se sente expulso de sua terra e sem lugar no mundo. (Riquelme, 1990, p. 11-12).

O trânsito na movediça vivência entre vida e morte e na iminência de seu desenlace na tortura é trazido pelo psicanalista Bruno Bettelheim (1989) que, após ter lutado pela sobrevivência nos campos de concentração nazistas, procurou, em seus escritos entender as estratégias para continuar vivo sob o holocausto. Ele deu, com seu suicídio no final da vida, um testemunho de que não conseguiu, ele próprio, libertar-se de seus algozes do passado.

Conheço os horrores a que se é submetido a ponto de fazê-lo desejar a morte como alívio; ou seja, à medida que as pulsões de vida enfraquecem, abre-se a porta para que a pulsão de morte domine o indivíduo. Eis a razão porque as vítimas puderam ser conduzidas para a câmara de gás sem resistir. (Bettelheim, 1989, p. 100, grifos meus).

O filósofo italiano Primo Levi, ao referir-se ao intelectual Jeán Amery, que esteve junto com ele no campo de extermínio de Auschwitz, assim se expressa:

Quem foi torturado permanece torturado. . . Quem sofreu o tormento não poderá mais ambientar-se no mundo, a miséria do aniquilamento jamais se extingue. A confiança na humanidade, já abalada pelo primeiro tapa no rosto, demolida posteriormente pela tortura, não se readquire mais. Para ele, a tortura foi uma morte interminável ... se matou em 1978. (Primo Levi, 2004, p. 20-21).

Primo Levi, nessa obra, examina o drama dos intelectuais. À semelhança de Jeán Amery, afirma que as vítimas de torturas que não conseguem desenvolver o sentido de sua pequenez diante da natural impotência de terem sido torturadas, que se tornam severos consigo mesmos para ganhar forças para "dar o troco", são tragados pelo ressentimento. Elas até conseguem recuperar a sua dignidade, mas pagam o preço altíssimo da destruição das próprias vidas, porque não estão seguras. Serão derrotadas. São, de fato, incapazes diante de tanta crueldade (2004, p. 109-126). Podemos entender esse processo nos moldes do "sentimento de culpabilidade" de que nos fala Freud?

De forma decisiva, a leitura tradicional da Psicanálise, restrita à imanência psíquica, é incompleta e não dá conta dessas questões. Embora Freud estivesse preocupado em desvelar minuciosamente a dinâmica dos processos psíquicos inconscientes, vilipendiados pela ciência de sua época, - o que se constitui, por si só em grande desafio - em toda sua obra, mais ou menos explicitamente, deixou evidenciado que não se pode menosprezar a ação do "meio externo" e da cultura quer no ego, no superego, quer na configuração do próprio id. Mais do afirmar que a Psicanálise é uma psicologia social da vida psíquica, analisou os efeitos regressivos de processos 
identificatórios narcísicos nos quais a idealização de um caudilho acaba por destruir a função superegóica de autoproteção da individualidade (Freud, 1923/1948c, p. 11191157). Ampliou e aprofundou mais ainda a compreensão da violência social internalizada sob o impacto da "maisrepressão" da sociedade em El malestar en la cultura (obra escrita em 1929-1930) quando demonstra que o inconsciente psíquico assimila a violência social internalizada como se originária do âmago da destrutividade psíquica e transformada em auto punição - "sentimento de culpabilidade" (Freud, 1930/1981a, p. 3017-3067).

Foi com essa convicção que retomei a leitura de alguns textos freudianos. As deformações teóricas que fui apreendendo de minha formação e prática psicanalítica esbarravam na limitada apreensão transferencial dos conteúdos do trauma psicossocial vividos pelos meus clientes. Estava impossibilitada de ajudá-los a alçar os conteúdos do sinistro e a ressignificá-los. Deixava-os, reiteradamente, insinuar-se, sem uma elaboração analítica do conteúdo do sinistro ao qual se agregara as representações terroríficas das experiências da prisão e tortura (Freud, 1930/1981a, p. 2483-2506). Inicialmente, muito me ajudou a apreensão do signifivado do $L o$ siniestro (Freud, 1919/1981b, p. 2483-2506) e os estudos que realizei sobre o processo de identificação com o agressor, a partir dos trabalhos de Anna Freud.

Para Adorno (1986), a relação que sustenta a identificação com o agressor tem o caráter de submissão, isto é, dá suporte político para a construção das "personalidades bem integradas" que não se oponham ao status quo. Afirma:

O objetivo da 'personalidade integrada' é reprovável porque exige do indivíduo aquele equilíbrio de forças que não existe na sociedade atual e não deveria existir de modo algum, porque aquelas forças não são da mesma natureza. Ao indivíduo se ensina a esquecer os conflitos objetivos que se repetem necessariamente em todos, em lugar de lhe ajudar a resolvê-los . . . sua integração seria falsa conciliação com o mundo irreconciliado e desembocaria provalvemente na 'identificação com o agressor', mera máscara da submissão. (p. 57-58) .

Nem todos os que estiveram em psicoterapia resistiram à superação desse horror vivido, e apenas um deles conseguiu contatar e dialogar com as representações desses momentos dramáticos de sua vida, reorganizando-a de forma integradora e bem criativa. Uma conseguiu liberar dessa angústia sua atividade intelectual e voltou à sua função de pesquisadora. Em nível de vínculos interpessoais, no entanto, continua vivendo a violência sofrida e as agruras impostas pela prisão e tortura - o "torturador internalizado" permanece fazendo estragos em sua vida. Tais vivências são deslocadas projetivamente para as suas relações com os demais. Outros destruiram- se no amargor e ressentimento por terem sido aviltados e vilipendiados em sua doutrina política. Um se aventurou no exercício de práticas místicas, exóticas e onipotentes em praça pública, o que o tornou desacreditado perante os antigos pares. A outra faleceu muito jovem de doença contagiosa, adquirida no envolvimento em práticas sexuais promíscuas - certamente: "suicídios camuflados" como analisa Primo Levi (2004, p. 109-126).

\section{Algumas faces e interfaces da violência de estado e da violência na sociedade}

Entendo que o psicólogo é um acolhedor das angústias irreversíveis inerentes à fragilidade da vida dos homens, um auxiliar na ressignificação de vivências reprimidas e/ou distorcidas; um aliado-denunciador das formas de relações sociais impostas pela sociedade que impedem a felicidade dos homens.

Esse meu texto exprime essas minhas preocupações e nele aponto algumas das diferentes expressões da violência na vida em sociedade como o principal legado perverso da cultura contemporânea porque elas impedem que os indivíduos realizem a sua individualidade em relações de dependência e acolhimento com os outros homens tal como postula Freud em "El malestar en la cultura" (1930/1981a). Procuro identificar algumas formas hostis que norteiam os valores da cultura na atualidade e oprimem a muitos, acabando por punir os que desobedecem a essas leis perversas. Exponho o modus operandi de certas estratégias da sociedade para manter cativos os indivíduos desavisados e desatentos ou já capturados pela apatia e conformismo.

Esta pesquisa não partiu do nada ou de um diletantismo intelectual, mas responde a um compromisso psicopolítico que permeia minha vida profissional e de cidadã há muitos anos. Aliás, foi amplamente gratificante derrubar os elmos e as mordaças da falsidade da neutralidade científica, que só respondem pela frieza no contato humano, sendo ela, em si mesma, mais uma forma de violência que atravessa os falsos postulados de uma certa ciência positivista, muito mais a serviço da manutenção do status quo do que da libertação dos homens.

Por exigência de questões vividas na minha prática de psicóloga clínica, necessitei adentrar a complexidade dos estudos atuais da violência de Estado e da violência social. Pude destacar a "privação" (Odália, 1983) como a essência do poder destruidor das violências em suas diferentes origens e níveis institucionais e sociais de abrangência. Vejamos, pois, o que o autor afirma sobre a privação:

Com efeito, privar significa tirar, destituir, despojar, desapossar alguém de alguma coisa; todo ato de violência é exatamente isso. Ele nos despoja de alguma coisa, de nossa vida, de nossos direitos como pessoas e como cidadãos. A violência nos impede não 
apenas de ser o que gostaríamos de ser, mas, fundamentalmente, de nos realizar como homens. A idéia de privação parece-me, portanto, permitir descobrir a violência onde ela estiver, por mais camuflada que esteja sob montanhas de preconceitos, de costumes ou tradições, de leis e legalismos. (1983, p. 86).

Localizarei, sucintamente, aquelas duas expressões da violência nomeadas acima, iniciando pela violência de Estado e de violação dos direitos humanos (FASIC, 1991) representadas pelos aparatos de repressão do Estado impostas por seus funcionários aos indivíduos e grupos.

O aparato policial-militar do Estadoé acionado quando este necessita estabelecer maior subserviência do povo. O Estado o faz por meios arbitrários e autoritários, quase sempre com objetivos de impor domínio à população para implantar certas mudanças estruturais da base econômica da sociedade - como ocorreu com as ditaduras militares na América Latina nas décadas de 60-70, a serviço da expansão imperialista do Capitalismo (Ianni, 1979, 1981). Nesse contexto, devem ser severamente punidos todos os que ousam desobedecer às premissas e ordens emanadas do governo despótico. A tirania reinante transforma a todos em potenciais criminosos - é a “criminalização da sociedade civil”, no dizer do sociólogo Octávio Ianni.

Dentre as formas mais cruéis de aplicação da violência pelo Estado, embora feita às escondidas nos quartéis militares e da polícia, estão a tortura e até as mortes executadas pelos agentes das Forças Armadas Exército, Marinha e Aeronáutica - e pelas Polícia Civil e Militar. As formas mais ostensivas de aplicação da violência, portanto, são as executadas pelo aparato bélico, militar e civil que sustentam as ditaduras, as guerras e os campos de extermínio, bem como as diferentes estratégias mortíferas de desaparecimentos, trabalhos forçados - digam-se, gratuitos, em empresas privadas (Primo Levi, 2004), torturas e mortes, terrivelmente, vis e humilhantes como as que foram produzidas pelo Nazismo nos fornos crematórios de Auschwitz.

Essas formas autoritárias de comando da sociedade ainda permanecem, e suas práticas criminosas se repetem hoje na base naval norte-americana de Guantânamo, em Cuba, e nos escondidos cadafalsos e porões de extermínio nos países do Oriente Médio, administrados pelos governos dos Estados Unidos e de Israel.

O acirramento das guerras após o 11 de setembro vem se tornando um importante instrumento social de obtenção de lucros econômicos (Chomsky, 2002), principalmente por meio da indústria armamentista e outras tecnologias de guerra. Além de questões geopolíticas táticas para a manutenção de hegemonias desses países, e a avidez de lucro com o petróleo em extinção, as guerras oportunizam importantes estratégias de manutenção de poder político e econômico por meio da potencialização do enriquecimento das empresas que sustentam suas economias monopolistas. Não só a produção bélica é beneficiada, mas também empresas vinculadas ao atendimento aos sobreviventes com mantimentos, roupas e medicamentos; as de engenharia e similares que se especializaram na reconstrução de cidades destruídas por conflitos armados. Muitos ganham dinheiro com o extermínio da humanidade.

A guerra atual não é mais a luta corpo a corpo ou com os artefatos de guerra terrestres. Ela é, preferencialmente, vertical e feita por meio dos avassaladores e terroríficos ataques aéreos, tal como ocorreu em Guernica, com o triste privilégio de há setenta anos atrás de ter sido a primeira cidade do mundo a ser destruída por um ataque aéreo. A técnica ficou conhecida como "tapete de bombas" (Richard, 2007). No contexto de justificativas das guerras atuais, essa tecnologia permite "o bombardeio pacificador", de que nos fala Santiago Alba Rico (2007), já que a sofisticação das tecnologias viabiliza o desvirtuamento de seu efeito avassalador destrutivo. Isso vem sendo feito por meio de símbolos sinestésicos tais como "resplandecentes e abundantes chuvas de luzes coloridas", potencializadas com as justificativas de serem "humanitárias, democratizadoras e pacificadoras" (p. 5). Os matadores são descaracterizados e são encobertas quaisquer responsabilidades individuais, coletivas e nacionais, porque esses agentes permanecem sem acesso perceptivo às conseqüências de suas ações. Essa "distância” (Bauman, 1998) permite não só a impessoalidade no uso das tecnologias bélicas, escondendo seu acionador, mas também a transferência da autoria da mortandade avassaladora de populações civis para as armas. Fica fácil dizer: foi "um erro técnico". Esse cinismo aplaca possíveis movimentos de denúncias e resistência, encobrindo os culpados pelos estragos humanos. Essa nova moral de guerra é chamada por Bauman (1998, p. 178196) de "ética da obediência" e é analisada, com muita perspicácia, em seu livro Modernidade e holocausto.

Ao contrário do horror e indignação despertados em muitos homens em decorrência da destruição de cidades e de massacres durante a Segunda Guerra Mundial, a banalização da violência das guerras atuais - que cada vez mais tomam conta do planeta - tem, na descaracterização da crueldade, sua principal força. Ela se expressa pela exposição do indivíduo, desde a infância, à violência por meio de filmes, jogos de combate $\mathrm{e}$ com armas oficiais dos Estados Unidos da América pela internet que vão, nesse faz-de-conta, reduzindo os perigos da guerra na mente dos indivíduos. A televisão exibe bombardeios de cidades como espetáculos pictóricos de fogos de artifício de hilariante beleza. Só quando interessa a exibição de força de um dos litigiantes, é que aparecem, na mídia, homens destroçados por mísseis poderosos. Essa linguagem imagética esplendorosa ofusca a 
consciência da irracionalidade dessas imagens (Debord, 1997) e impede os efetivos testes de realidade do terror que espalham.

Os estudiosos, porém, realçam o uso, cada vez mais frequiente, de diferentes estratégias de amedrontamento da população (Glassner, 2003), pois elas funcionam como coação social para obter a complacência das populações para a arbitrariedade da invasão bélica de outros países.

Há outras violências de Estado, no entanto, que atualizam o poder de coerção mais sutis, de violência e da exclusão social, ao usarem outros aparatos institucionais de repressão social. Trata-se da estrutura judicial - regulação da sociedade por meio de leis e mecanismos de contenção social - que se expressa por meio de prescrições em sentenças feitas por juízes dos diferentes tribunais públicos. Nelas, ficam qualificados os crimes, as penas a serem aplicadas àqueles que cometeram algum delito, a punição de diferentes maneiras até a reclusão nas delegacias, nas cadeias e nas penitenciárias. É importante frisar que o ideário do direito está atravessado pela hierarquia e privilégios das relações de classe social (Racanello, 1985), deixando impunes os crimes cometidos pela elite hegemônica (Caniato, 1999a).

Aguardemos, porém, o desenrolar da história, pois entendemos que a violência desvairada, que se espalha, na atualidade, como barbárie ou novo holocausto, como apontam muitos cientistas sociais, significa o estertor de uma forma de organização social prestes a seu fim. Por enquanto, fiquemos com o acalanto esperançoso da sabedoria de Hanna Arendt (1973) que afirma:

Ainda uma vez não sabemos onde tais desenvolvimentos vão nos levar, mas sabemos, ou deveríamos saber, que todo declínio de poder é um convite aberto à violência - mesmo porque os que detêm o poder e o sentem escapando das mãos, sejam eles governantes ou governados, sempre acham difícil ressitir à tentação de substituí-lo pela violência. (p. 136).

Caminhemos um pouco pela violência social à guiza de situar algumas instituições e estratégias sociais que a explicitam.

Estamos assistindo, cada vez mais no mundo de hoje, à destruição da política e da cidadania que corre à matroca do poderio econômico para o qual o único direito sobre a face da terra é o da propriedade privada, e o único bem a ser preservado é o dinheiro (Martin \& Schumnann, 1999). Atualmente, a subalternização do humano é inconteste. Muitas estratégias têm sido desencadeadas para destruir as individualidades e a vida coletiva.

O apogeu do processo chamado de "civilização" como alguns estudiosos nomeiam o período histórico atual de "desenvolvimento" da humanidade - identificase, de fato, como aquele das maiores barbáries da história do homem (Bauman, 1998; Sader, 2006). Talvez como nunca, e com tamanha intensidade, exista a privação e a supressão social do atendimento às necessidades biológicas inerentes à preservação da vida humana, a fome. Esse fato constitui importante aspecto da violência estrutural (Ugalde \& Zwi, 1991) inerente ao modo de produção e distribuição dos bens produzidos socialmente sob o capitalismo. Essa impossibilidade de acesso ao alimento é uma das formas atuais de extermínio dos homens. Intencionalmente?

A matriz de toda a violência social, no entanto, encontra-se nas relações de trabalho. Na base econômica da sociedade, a expropriação do trabalhador aparece, essencialmente, pela apropriação privada do produto do trabalho, como analisou Marx.

Por outro lado, a ideologia vem sendo massivamente utilizada para promover a distorção e o encobrimento simbólico da violência nas relações de trabalho. Por meio de uma atribuição valorativa enganosa dada aos indivíduos, para intensificar a exploração dos trabalhadores, exige nas organizações empresariais o "homem flexível" (Sennett, 2001). O lema do poder hegemônico é manter homens ignóbeis sob controle e sustentar o comando da "massa adestrável" para impedir que os indivíduos se tornem verdadeiramente livres - sujeitos da cultura -, agentes de resistência política e mudanças sócioeconômicas. É preciso que continue a existir uma sociedade de indivíduos conformados ao sofrimento psicossocial e acuados pelo pânico (Glassner, 2003) para que se mantenham a hegemonia de classe e a sustentação do status quo.

O controle social dos indivíduos pela lógica da mercadoria deixa, certamente, inúmeras distorções destrutivas no desejar, sentir, pensar dos indivíduos, e contamina, de forma perversa, os vínculos entre eles (Mariotti, 2002). Tal fetichização exige a cooptação de indivíduos isolados, deformados e fragilizados pelo individualismo imperante, $\mathrm{e}$ contraria a necessidade de dependência inerente às relações entre os indivíduos singulares que necessitam cuidados mútuos no acolhimento. Essa privação-afastamento dos pares é imposta, sorrateiramente, pela mídia que já forja os "pseudo-indivíduos" estandardizados para mais facilmente serem aliciados pela indústria cultural (Adorno \& Horkheimer, 1985). A sociedade de consumo exige que todos os indivíduos sejam servos fiéis de um único senhor, que os promete alçar ao mundo dos "prazeres infindáveis". Seus reais desejos estão em suspensão, seus sentimentos voltados para um único objeto - a mercadoria - e seus pensamentos estão sob o controle inconsciente da farsa das ideologias consumistas. A felicidade está deslocada da vida de relações entre os homens e se expressa pela captura da libido pela mercadoria e na satisfação de ter o vínculo amoroso sexual substituído pelo contentamento de ter dinheiro para tomar o "banho de loja" (Arreguy \& Garcia, 2001). 
Nesse âmbito da vida dos indivíduos, a violência social se configura, preferencialmente, como exercício de manipulação político-ideológica e de opressão/conformação por meio de diferentes estratégias e instrumentos de ameaças, mais ou menos, sutis. É, portanto, uma violência simbólica. A violência simbólica, segundo Costa (1986), se encarrega de capturar o mundo interno dos sujeitos para substituí-lo pela internalização de formas de ser, desejar, sentir, pensar e agir que interessam à manutenção da sociedade. A emergência de indivíduos autonômos é contida pela difusão maciça de modelos identificatórios que promovem a estandardização dos indivíduos, tornados "máscaras mortuárias" (Adorno \& Horkheimer, 1985). O mascaramento do real e a imposição social de formas-de-ser-indivíduo - padronização viabilizam um controle social mais eficaz que não seria possível sob a permissão da diferença e da diversidade. Esses modelos são difundidos, em especial, pela mídia e, para melhor controle social, eles são cada vez mais comuns a todos os indivíduos do planeta.

A vida de relações na sociedade também está sob controle. A pretensão do poder hegemônico é provar que tais relações são universais, perenes e imutáveis como estratégia para mantê-las como estão. Muitas culturas diferentes vêm sendo destruídas e sugadas pelos ditames da globalização (Baudrillard, 2002) e até exterminadas pela "sucção" de hábitos, costumes e atitudes, modificandose para modelos necessários à manutenção do poder, em virtude da imposição do conquistador (Ali, 2003). As diferenças individuais e culturais não podm existir, pois elas ameaçam o status quo; têm de desaparecer, serem suprimidas. É freqüente a atribuição de malignidade aos grupos discordantes e/ou subalternos que passam a ser identificados socialmente como perigosos e merecedores de exclusão social, prisão ou assassinato - "categoria de acusação" (Velho, 1997).

Nessas circunstâncias aciona-se o aparato de repressão do Estado que, com o respaldo social da população, já manipulada a favor dos que detêm o domínio econômico e se apropriaram do poder político passa, também, a hostilizar esses grupos marginalizados socialmente. Pedem a punição dos "culpados", vangloriam-se ao vêlos sendo castigados de diferentes maneiras: desde a vistoria policial acintosa, o uso de torturas e até mesmo do uso de armas de fogo. Essa população vive sob o estereótipo de "classe perigosa" e é marcada com a qualificação de infratores (Coimbra, 2001). O autoritarismo vai criando novas armadilhas, ficando justificada a imposição de estratégias de vigilância, contenção e extermínio desses grupos com a plena aceitação social de muitos outros homens (Caniato \& Nascimento, no prelo).

A atribuição de malignidade recai, ainda, sobre grupos culturais, muitas vezes diferenciados por uma religiosidade bem definida. São satanizadas por suas manifes- tações espirituais, transformadas em álibi para fazer a sua condenação social e, quiçá, para alijá-los da face da terra com a morte. Para eles, só existe uma alternativa: são "terroristas" e devem ser punidos com a morte. (Chomsky, 2002). A estratégia de captura desses indivíduos reside em difundir esse estereótipo no mundo atual globalizado, visando ao apoio dessa "massa" que funciona como um ancoradouro do poder instituído no uso da violência contra os integrantes desses grupos. Essa cumplicidade para matar exprime uma terrivel faceta da "banalização da violência" que se espraia nas sociedades modernas (Arendt, 2000).

Utilizando-se dessas estratégias maniqueístas é que a violência social vai atravessando o tecido social e se articulando com a violência de Estado para afastar e/ou exterminar esses indivíduos vítimas que resistem às estereotipias. Intensifica a opressão e a exclusão sociais e consegue, assim, manter a "sociedade protegida e em segurança"... A violência social complementa, pois, a violência de Estado e ambas atuam integradamente. Afinal está em jogo a defesa de uma organização social que beneficia uma minoria de homens que não quer perder seus privilégios hegemônicos e de quem o Estado continua sendo aliado.

Não há dúvida de que essas formas de violência efetuam a repressão dos indivíduos na sociedade e estão a serviço das injustiças e das desigualdades sociais: o controle social dos indivíduos é exercido para a sustentação de privilégios de classe de uma minoria que retém os bônus da lucratividade na produção e no consumo das mercadorias. Os demais indivíduos vivem sob a vigilância cada vez mais acirrada da sociedade.A invasão da privacidade se coloca como normatização cínica, sendo cada vez mais efetuada por agências privadas que recebem essa incumbência dos Estados. Essas ações de violência são justificadas como exigência para uma suposta segurança dos membros da sociedade e, embora venham sendo cada vez mais invasivas da vida privada dos indivíduos, são também massivamente difundidas sob formas hilariantes, para não dizer debochadas, tais como "sorria, você está sendo filmado" (Caniato \& Nascimento, no prelo; Martorell, 1999).

Apesar da crueldade das intervenções dessas violências na vida dos homens, apenas alguns poucos indivíduos e/ou grupos humanos se rebelam contra essa barbárie. Os demais apenas sofrem porque são apáticos e conformados. São cúmplices, portanto, de toda a desumanização que se impõe à vida individual e coletiva dos homens na contemporaneidade.

Em síntese, o homem está vivendo numa sociedade que o transformou em lixo e em "vida desperdiçada" as criaturas humanas e seus ideais (Bauman, 2005). Para tanto, o Estado utiliza diferentes e poderosas estratégias de violência condizentes com a fragilização dos indivíduos e 
com a destruição de vínculos solidários nas relações coletivas (Bauman, 2004). O Senhor Capital reina soberano!

\section{A internalização da violência e algumas de suas implicações na relação subjetividade e cultura}

Tanto a violência de Estado quanto a violência social estão a serviço da manutenção de um tipo de relações entre os homens e de uma forma de ser "indivíduo". Essa relação responde à permanência de certa organização econômica e de distribuição do consumo, no caso, o princípio capitalista. Embora os estragos da violência de Estado se manifestem de forma mais materializada na destruição corporal (tortura, encarceramento, morte), as representações simbólicas de suas seqüelas ficam regurgitando na vida mental como experiência traumática de horror (Viñar \& Viñar, 1992). A violência social strictu sensu, embora não menos destrutiva, é de mais difícil apreensão porque suas intenções são camufladas, disfarçadas e ocultas. Estão enredadas na complexa rede de interesses sociopolíticos e econômicos que as originam. O emaranhado de causalidades e de relações que a estruturam dificulta seu desvelamento por um olhar mais ingênuo vinculado ao senso comum, daí a sua maior penetração em camadas cada vez maiores da sociedade. Suas manifestações exigem uma interpretação à luz de uma visão de homem, dentro de uma perspectiva de classe social e necessita uma decodificação de sua significação ideológica: uma leitura comprometida com a felicidade dos homens. Só assim se torna possível apreender a origem da violência, as suas intenções e os alvos de quem a produz, os objetivos a serem alcançados e quem deve ser atingido. Suas vítimas, na maioria das vezes, não identificam, em suas vidas, a presença da violência de origem social. Isso porque tais representações internalizadas são capturadas diretamente pelo inconsciente psíquico e/ou por uma estrutura egóica fragilizada que permite identificações do indivíduo com objetos sociais perversos - via a libidinização sublimada desses objetos - (Freud, 1923/1948c) que contrariam as possibilidades de felicidade dos homens.

Nomearam-se, anteriormente, várias expressões da violência. Aqui serão examinados, preferencialmente, os estragos psíquicos da violência simbólica, veiculada pela indústria cultural (Adorno, 1986), cujas representações são internalizadas e passam a integrar a vida mental dos indivíduos. À luz da Psicanálise pode-se buscar a compreensão de alguns dos descaminhos dessa violência nas relações entre os homens e em seus próprios psiquismos. É essa internalização inconsciente que confunde os sujeitos. Eles facilmente interpretam como provenientes de seu âmago, muitas representações desejantes, afetivas e ideativas que tiveram origem no exterior, em sua vida de relações na sociedade.Éo processo de identificação projetiva-introjetiva que permite esse trânsito interativo entre o mundo externo e o mundo interno, as trocas transferenciais/interrelacionais entre a subjetividade e a cultura. Não há dúvida de que, na autopunição, que esse processo desencadeia, se mobilizam estruturas mentais arcaicas e de conotação tanática (Freud, 1930/1981a). Elas se acoplam à violência de origem social, configurando-se como um vínculo simbiótico e de cumplicidade inconsciente do indivíduo com a violência social internalizada.

Qual o caminho que toma esse processo com as determinações da cultura na relação dos indivíduos entre si a partir dessa imersão narcísica desintegradora? Não há duvida de que os indivíduos repetem compulsivamente consigo e, no vínculo com os outros, essa orientação sadomasoquista primária. Na contemporaneidade, agrava-se essa morbidade pela heroificação da violência que passa a significar o grito estertor passível de produzir o resgate da identidade perdida. Entretanto, com frequência, emergem práticas sociais auto/hetero/punitivas de suspensão de corpos, rituais de sacrifícios de escarificação, body modificacion e até pactos de morte coletivos pela internet (Neiva, 2006). Muitas dessas práticas falam do desespero de estar vivo ou refletem uma forma perversa de testar a capacidade heróica de morrer/viver, quase sempre com o testemunho/cúmplice de um outro parceiro: são difundidas práticas de alto risco de morte com a suposta intenção de recuperar a vida.

Se desconsiderarmos a interação mundo internomundo externo, tenderemos a patologizar os indivíduos que se envolvem com essas práticas contempâneas. Considerar a primazia do inconsciente, com o seu amálgama vida/morte impulsionador de todo o aparato psíquico e objeto central das preocupações da Psicanálise, não significa fazer uma leitura reducionista da atividade mental se estamos atentos à penetrabilidade do próprio inconsciente por injunções externas aos indivíduos. Freud já falava dessa porosidade desde a sua Metapsicologia (1913-1917/ 1948b). Ignorar a dimensão relacional da estrutura psíquica e considerá-la como mônada, abre a perspectiva de uma postura cúmplice da culpabilização social que atribui aos indivíduos todos os seus fracassos, bem nos moldes de uma sociedade que se propõe a ser igualitária mas que, de fato, exclui e violenta os indivíduos (Caniato, 1999b).

Essa sujeição dos indivíduos aos ditames arbitrários de uma sociedade autoritária só se torna possível porque tais indivíduos vivem, de forma normatizada, a invasão de sua vida interior e individual, a destruição de sua necessidade de amparo pelo outro, o abandono da satisfação de suas exigências essenciais de sujeito, a ilusória representação de si mesmos como "heróis e gestores de sua vidas", impregnadas pela morbidez do "personalismo narcísico individualista". Eis um retrato desse homem: 
Aos que se adaptam ${ }^{1}$.

O que acontece com seus olhos que não vêem?

O que se dá na sua cabeça

que não entra a certeza de que está praticamente tudo deturpado

e que o ser humano está vivendo errado?

$\mathrm{O}$ que acontece que o Sol te queima e o tempo te enjoa?

O que te maravilha?

O que faz com sua vida?

O que fazem com o amor?

$\mathrm{O}$ que acontece que sua boca consente

e sua garganta não cospe o catarro que gera?

$\mathrm{O}$ que acontece que seus cabelos se orgulham

da lama encravada do limbo onde abre as pernas e geme?

Puta! até onde você quer se prostituir para se adaptar neste mundo?

O que você ama?

O que faz com sua vida?

$O$ que estão fazendo com a humanidade?!

$\mathrm{O}$ que acontece que mesmo a violência lhe encubrindo,

você se esquiva e faz com que durma alienada toda verdade?

$\mathrm{O}$ que acontece que mesmo seus olhos vendo, sua cabeça entendendo,

sua boca vomitada,

seu cabelo raspado,

você continua se masturbando com o discurso da televisão?

O que sobra é o corpo de mortos-vivos. Esse vazio interior, essa paralisação da vida interna, essa superficialidade enganosa do viver o ser-um e a negação da alteridade de um-outro; a impossibilidade do existir na diferença sem ser atacado; o enfraquecimento do acolhimento do coletivo e a impossibilidade de relações marcadas pela solidariedade fundam a sacralização dos corpos - foi o que sobrou. Passa-se a exigir tudo: "Aguente! - seja resiliente!'- como pensam alguns intelectuais, isto é, sejam portadores de grande integridade psíquica e poderosa saúde mental! Até o que resta de sua identidade, embora superficialidade, continua sendo objeto de ataque. Triste beleza aparente de "corpos sarados, malhados, escarificados, dependurados como carne bovina" que apenas, tal como robôs, identificam-se cegamente com as exigências sociais de manutenção de mentes aprisionadas e escravizadas: a troca com a mercadoria (Lowen, 1983)! Repito: "vidas desperdiçadas"... (Bauman, 2005).

Estamos diante de injunções do narcisismo de morte de que nos fala Green (1988) destruidor da vida subjetiva, porque dela se retira tudo que é seu, colocando-se em seu lugar, impositivamente, modelos identificatórios que lhe são alienígenas: o indivíduo acaba por sucumbir ao que Maci (2005) chama de poder imaginário do narcisismo. Como pseudo-indivíduos (Adorno, 1986) e sob intenso sofrimento narcísico, exibem-se em rituais de isolamento macabro, ostentando uma auto-suficiência que deixa desvelar a representação de fantasmas com que desfilam/exibem para o mundo o que deveria ser o "mundo da vida - o mundo dos homens". Troca-se tudo, sorrateiramente, pelo mundo do "prazer delirante do consumo". Nesse conluio mórbido com a mercadoria, no nirvana da indiferença dos "deuses" (mortais, sem o saber), dos "templos do consumo" (shoppings centers), o outro não importa. Pior ainda: inflados na sua identidade por esse outro impessoal (dinheiro), a ele se submetem e se iludem. Seu "parceiro" é o reino da mercadoria (Mariotti, 2002). Mas ele é intimado a ser suicida (real ou simbólico) já que, para tentar sobreviver com o seu parceiro/rival, o poderoso dinheiro tem de se inserir na lógica perversa do consumismo e ser novamente um homem sob a corrosão do caráter (Sennett, 2001), se quiser "ser bem sucedido" na vida. Na há duvida de que, nessa identificação, mais uma vez se exibe a inconsciência da autopunição que tem sua origem na destruição mais ou menos intencional da maioria dos homens para que o reino do lucro, do dinheiro permaneça como o único Senhor.

Quanto poderia o homem se proteger melhor se impulsionado por seus desejos verdadeiros, centrado no significado diferenciador de seus afetos e orientado pela sabedoria relacional de seu pensamento? Quanto poderia o homem também lidar melhor com a sua finitude sem se expor à violência de "ser herói" ou sucumbir no individualismo devorador na corpolatria - culto `a exterioridade $\mathrm{e}$ à aparência da moda - para o qual vem sendo conduzido.

$\mathrm{O}$ homem certamente tem condições de recuperar a dignidade abafada e contar com sua força de vida para estar em contato real e verdadeiro com essa forma de vida perversa, subvertendo-a. Seu discernimento entre o bem e o mal (há muito expulsos da sociedade contemporânea sem ética e sem valores morais) certamente permitiria separar o amigo do inimigo e se fortalecer no e com o amparo protetor de quem também o ama. Vale a pena termos, como meta para a mudança dos rumos das relações entre os homens, em respeito à dependência estrutural dos indivíduos entre si, que o amálgama da libido / agressão possa nutrir a solidariedade necessária à felicidade dos homens, tal como postula Freud em El malestar en la cultura:

Mi amor es para mi algo muy precioso, que no tengo derecho a derrochar insensatamente. Me impone obligaciones que debo estar dispuesto a cumplir con sacrificios. Si amo a alguien, es preciso que éste lo merezca por cualquier titulo. . . Mereceria mi amor si se me asemejara en aspectos importantes, a punto tal que pudiera amar en él a mi mismo; lo mereceria si fuera más perfecto de lo que yo soy, en tal medida que pudiera amar en él al ideal de mi persona; deberia amarlo si fuera el hijo de mi amigo, pues el dolor de éste, si algún mal le sucediera, también seria mi dolor, yo tendría que compartilo. En cambio, si me fuera 
extraño y si no me atrajese ninguno de sus propios valores, ninguna importancia que hubiera adquirido para mi vida afectiva, entonces me seria muy difícil amarlo. Hasta seria injusto si lo amara, pues los míos aprecian mi amor como una demostración de preferencia, y les haría injusticia si los equiparase con un extraño. (1930/1981a, p. 3044).

\section{Um retrato multifacetado e fragmentado do indivíduo contemporâneo}

Embora, talvez, já estejamos a caminho da construção de um outro mundo onde os homens possam ser felizes, não podemos deixar de estar atentos aos destinos dos indivíduos que são forjados na sociedade contemporânea. Não há dúvida de que diferentes formas de violência, cada vez mais usadas, ostensivamente, para o controle de corpos e mentes, tendem a tornar os indivíduos docilizados e conformados com sua tragédia individuosocial. Enquanto o poder hegemônico do Capital espraiase sob formas deletérias de organização do trabalho e novas formas de estruturação das demandas de consumo (com o uso intensivo da mídia, em especial), os homens são capturados para aceitar, quietos, a ganância de uns poucos, que fazem as guerras para pilhar o que a natureza e a cultura reservaram para todos os homens!... É preciso ser forte, dócil e obediente às ordens do poder do arbítrio; ser rígido o suficiente para jamais trair os superiores; ser cínico, moralmente, para viver em uma sociedade que já não tem mais valores éticos para resguardar as relações entre os homens e entrar no jogo do “salve-se quem puder". É preciso desenvolver a frieza afetiva para encaixar nas fraldas do poder, bajulando os poderosos, isto é, os que têm dinheiro para, se preciso for, matar o antigo amigo e se equilibrar na armadilha de uma corda bamba que aponta para um falso sucesso ou para a queda fatal no abismo dos despossuídos de tudo.

Nessa sociedade, a supercompetição destrói as relações fraternas e não há lugar para o amparo mútuo entre os homens (Freud, 1930/1981a). É preciso se tornar indiferente à dor alheia e ignorar seu próprio sofrimento, banalizar a violência sofrida e tratá-la, apenas, como originária das próprias entranhas carcomidas. Por que reivindicar se o indivíduo é considerado desprezível e, portanto, não tem quem o acolha? Talvez, apenas, receba algumas esmolas anônimas, porque na sua miséria é objeto de medo e de repulsa. Não pode de forma alguma reclamar já que não merece sair da penúria e nem saberia o que fazer se o rumo de sua vida mudasse e viesse a florescer!... Pune-se antes que possa identificar de onde vem seu sofrimento (Caniato \& Castro 2004).

Indignação, como? Para onde pode levar essa inquietude que começa a vibrar dentro dele? Mas ele está só e todos ao seu redor estão apáticos, ignoram o que ocorre com eles mesmos. Não encontra quem mostre qualquer inquietude; ele chega a se achar anormal. Ninguém sinaliza sentir sequer a estranheza de uma "vida desperdiçada", mergulhada na hostilidade e na amargura, e que queira fazer alguma coisa para mudar em nome de um apelo de vida. Talvez os outros nem saibam que isso existe; tão habituados estão à infidelidade e à traição. Mas ele continua inquieto!... E impotente! Se se revoltar, não encontrará quem lhe seja solidário e corre o risco de ser preso. $\mathrm{O}$ medo de ser punido se intensifica, pois certamente a polícia virá pegá-lo; os outros apáticos irão para a cadeia sem saber por que, pois estavam silenciosos e não estavam fazendo baderna alguma. Ninguém se mexe, todos estão acuados, assustados, até e se afastam correndo daquele "maluco" que pensa. Ele sozinho nada conseguirá fazer, pois o grande aparato de violência e repressão já desconfiou de sua alegria e a polícia foi acionada pelos vizinhos de sua residência. Não, não pode e não adianta mudar nada!... A perplexidade toma conta dele novamente, pois sempre ouviu dizer que só Deus ou o destino sabem dos caminhos para o homem... Mas algo dentro dele já não está mais do mesmo jeito: ele começou a pensar e a sentir-se com direitos?!!... Dentro dele floresce a vida que não é entendida por quem o cerca; mas ele não se deixa enganar pela mensagem do amor que começa a nutrir toda a sua vida... Mas ele é só um... Se não quer ter a rejeição de todos ou ser punido terá de adiar o imperativo de viver o "mundo da vida" e, afinal, o seu sonho fala disso. Agora terá que desistir ou adiar porque está só...

Esse pode ser um pequeno retrato do homem solitário que tem uma força de vida, mas não tem acolhimento do outro, e não sabe onde encontrar um parceiro; que é obrigado a acolher o massacre que a humanidade está vivendo porque é impotente e não consegue diferençar claramente os malfeitores para poder responsabilizá-los pelo atoleiro da morte a que, de diferentes maneiras, todos estamos expostos. Esse homem cai também, desanima e se conforma com o sofrimento e, se não se frear, será mais um a matar. O sadomasoquismo é a forma básica do viver atual?

Esse é hoje o terrível fenômeno da "banalidade do mal" muito bem analisado pela filósofa Hanna Arendt (2000). Os cientistas mais sensíveis à destruição do humano dos homens que atravessa o apogeu da sociedade da avareza (Mariotti, 2002) - considerada como "civilizada" pelos que não se importam com a degradação da vida dos homens - são unânimes em denunciar a permanência do holocausto nos dias de hoje (Bauman, 1998; Primo Levi, 2004). Este holocausto é pior do que o da época do Nazismo de Hitler, porque seus efeitos daninhos estão potencializados pelo uso dissimulado do avanço tecnológico e da comunicação on-line; é estimulado pela supercompetição entre os homens no mundo do trabalho e destrói deliberadamente as necessárias relações de aco- 
lhimento no cotidiano. Tudo isso objetiva potencializar a avareza e o lucro, inexistindo qualquer escrúpulo que possa conter a ganância desenfreada, mas camuflada: se necessário, façamos as guerras, mas vamos, de forma leviana, disfarçá-la com a exibição de espetáculos de fogos de artifício difundidos pela televisão para todo o planeta enquanto milhares/milhões de homens estão morrendo... (Alba Rico, 2007)

A tecnologia da informação vem permitindo a vigilância (Caniato \& Nascimento, no prelo) de todos e de cada um - GPS, Echelon e similares - e propiciando os efeitos condicionantes da degradação das mentes pela virtualidade que vem substituindo, ilusoriamente, os contatos reais entre homens, tornando-os isolados e solitários (Sodré, 2002). Destruído o outro concreto da identificação e do investimento libidinoso no cotidiano, pairam inflados os personagens onipotentes gerados pela sociedade de Matrix. Cada um e todos não resistem ao apelo voraz e destrutivo da sedução (Lucchesi, 2002) e se permitem deixar sugar a sua interioridade. Abandonam a identidade autônoma para copiar as bravatas propaladas por esses ícones poderosos, sempre bem sucedidos porque sempre vencem. Caem no engodo da traiçoeira sedução, aspirando chegar, pelo menos, à vez de entrar no "palco do suplício" para, pelo menos aí, serem vistos (Aidé, 2002). Todos são "chamados a serem heróis" e, como se heróis pudessem de fato ser, passam a adentrar o mundo fantasioso de personagens fantásticos, mesmo que seja como "Segunda Vida". Desafiam tudo sem pensar em preservar a vida, pois se julgam dotados de supostos poderes da imortalidade. Precisam sempre testar a sua onipotência e derrubar seus limites que prefeririam ignorar existir (Caniato, 2000).

Tolos heróis! Exigem de si esforços sobrenaturais para provar a essa vil sociedade que "agüentam todos os maltratos que o destino lhes presenteou" (Martín-Baró, 1987). São confirmados, em seu engano, por uma leviana adjetivação que a "ciência" lhes concedeu e que ganha o status de verdade comprovada: são portadores de grande integridade psíquica e saúde mental. São resilientes! Entretanto, o que ocorre, de fato, é que esses indivíduos são os que, no contexto social atual, se vergam aos ditames da tirania, opressão e vivem "tranqüilos" sob coação. Perderam a capacidade de discriminar o que lhes faz bem e o que lhes faz mal e não podem decidir sobre o seu sentir-fazer porque inexiste a autodeterminação para orientar suas próprias vidas. O indivíduo, sob a resiliência, está obrigado a sempre dizer "sim" para não ser taxado de retrógrado, incapaz e insano. Mesmo quando está sob chicote, não pode mostrar fraqueza, muito menos exibir os estragos que está vivendo. Nunca pode dizer "não" para não ser interpretado como incompetente e covarde. Deduz-se que sob a resiliência, a felicidade se confunda com o sofrimento ou, que nessa mistura se louve o "cur- tir" a vivência do prazer na dor (sadomasoquismo) e que se negue qualquer expressão de seus limites e finitude. Exigir que os indivíduos se calem diante da dor é autoritarismo fascista.

A estratégia do engano e da mentira (Caniato, no prelo), amplamente usada nas relações entre os indivíduos, agride a inteligência e ofende aos que ainda conservam alguns princípios éticos. Está na moda e é, amplamente divulgada pela mídia, a proposta oficial de inclusão social. Belo slogan no qual se iludem alguns ingênuos e bondosos educadores desavisados, tornados porta vozes do poder instituído, ao se deixarem enganar pela farsa de uma suposta inclusão social. Essa "inclusão" está apenas alimentada no/pelo jogo ideológico do assistencialismo governamental, sustentado por meio das "falsas ofertas de bem-estar social" (serviços ou bens materiais do tipo "bolsa alimentação") e justificadas como uma ação política não-segregacionista e sem preconceitos em relação às populações, de fato, excluídas socialmente. Será que merece punição quem descobre que a farsa da inclusão é uma forma, ideologicamente fundada, sem encobrir os péssimos serviços de educação e saúde que, em nome da inclusão social, estão sendo oferecidos às populações pauperizadas? Principalmente, será ético e saudável estar incluso ou incluir alguém em uma sociedade na qual a barbárie vai-se instalando acintosa e sorrateiramente? (Dufour, 2001)

A violência se espalha na vida em sociedade e, quando não mata de miséria e penúria, vai se metamorfoseando, sob formas simbólicas, em promessas falsas de felicidade que enganam a muitos desavisados, que não puderam desenvolver uma reflexão crítica, permitindo-lhes detectar as armadilhas e os estertores das perversas identificações propostas pela indústria cultural da sociedade que exorta a luxúria. (Adorno \& Horkheimer, 1985).

Tal euforia satânica deixa, no entanto, traços irreversíveis do terror/horror que se espalham destrutivamente no interior de cada um (Freud, 19161918/1948a). O medo não mais serve à vida, como analisou Freud (1916-198/1948a), pois não é mais permitido aos homens discernir sobre a gravidade dos riscos sob os quais vive. O indivíduo, então, não aciona os mecanismos de proteção à vida, impostos por sua finitude. Perdidos e impotentes, não conseguem reter o avanço da cultura do medo que se espalha (Glassner, 2003), levando, de roldão, a supressão da vida porque está encolhida, escondida e acuada. Expõe os homens ao estertor paradoxal de suas forças vitais, ao detonar contínuos perigos e riscos que exigem novos desafios para esse enfrentamento, um feito possível somente para o "herói" - o par antitético da onipotência /impotência humanas. Os indivíduos são mantidos paralisados sob o afã de possuir uma fortaleza heróica, inexistente dentro de cada um (Forrester, 1997). Este é o grande engano fomentado 
pela ubiqüidade, pela prostração mórbida, pela grande imersão no puro inconsciente tanático. (Freud, 1930/ 1981a). Pior ainda: só chegam, por parte de outros indivíduos, as condenações, as repreensões e as cobranças por seu fracasso porque não identificam a fraqueza como existente, também, em si mesmos.

O coletivo de acolhimento está sob censura, no mundo em que o "valor" exaltado é a euforia de um indivíduo-rei. De fato esse "personagem" está esvaziado e deposto de suas especificidades humanas (individualismo) e, em conseqüência, ele é o único condenado e culpabilizado pelos demais por todas essas ofensas/mazelas em que vive. Só competiria ao indivíduo, portanto, com seus esforços solitários, parar de se punir e ir à luta, oxalá, sem mexer em nada que está a priori posto socialmente (Dejours, 2000).

Sintetizando: a manipulação do indivíduo, a indústria cultural, a suspeição entre os indivíduos, a vigilância e o controle sociais, a cumplicidade mórbida subjetiva, o esfacelamento dos vínculos entre os homens, as banalizações do mal, da injustiça social, da violência, do sofrimento e da dor, o pavor gerado pela cultura do medo e a aplicação arbitrária, discriminatória e excludente das leis - a impunidade reina soberana entre os poderosos (Caniato, 1999a) que regem a ordem social, - são alguns dos atributos das violências sociais e de Estado que produzem o sofrimento psíquico, e convivem de mãos dadas para destruir a autonomia dos sujeitos. Monta-se uma poderosa rede de inversão ideológica dessa verdade por meio da qual os indivíduos vitimizados se transformam nos algozes de si mesmos, ao serem culpabilizados como sendo incapazes quando não conseguem ter sucesso na sociedade. $\mathrm{O}$ auto-respeito e o amor próprio são destruídos, e essa retirada do investimento libidinoso em si resulta a deteriorização de outras instâncias psíquicas, como a da reflexão crítica e a das relações afetivas. Tornam-se homens movidos a cabresto, tendo de seguir as formas de desejar, sentir, pensar e agir que lhes são impostas pelos modelos identificatórios construídos socialmente: todos são iguais, amalgamados simbioticamente pelo individualismo necessário ao status quo. Sob a repetição compulsiva da mesmice, inexiste a possibilidade de trocas fraternas que possam fortalecer os laços de solidariedade entre os diferentes, trocas viáveis, apenas, na diversidade. Cada um está sozinho, sem poder envolverse no enamoramento de um outro diferente e nem dele receber amparo. Segue, apenas, a forma impessoal que lhe é imposta pela sociedade globalizada da mercadoria e do consumo (Baudrillard, 2002).

A sociedade atual produz e mantém a morte camuflada, tanto na vida íntima dos indivíduos como também por meio das regras (lógica da supremacia do dinheiro e do lucro acima de qualquer outro valor) que orientam as relações sociais. A destruição se espraia por todo o plane- ta Terra, disfarçada sob formas democráticas de governo, manipulação da inserção social pela via do assistencialismo, políticas públicas chamadas de "equalizadoras", mas geridas pela injustiça social e pela inexistência de direitos humanos (Caniato, Cesnik \& Araujo, 2005).

Como assevera Hanna Arendt (2002), de forma categórica e trágica, ao examinar a inconsciência e a persistência destrutiva da destruição do pensamento:

. . . a longo prazo, o resultado mais certo da lavagem cerebral é uma curiosa espécie de cinismo - uma absoluta recusa a acreditar na verdade de qualquer coisa, por mais bem estabelecida que ela possa ser. Em outras palavras, o resultado de uma substituição coerente e total da verdade dos fatos por mentiras não é passarem estas a ser aceitas como verdade, e a verdade ser difamada como mentira, porém um processo de destruição do sentido diante o qual nos orientamos no mundo real - incluindo-se entre os meios mentais para esse fim a categoria de oposição entre verdade e mentira. . . Esse é o motivo por que a mentira coerente, em termos metafóricos, arranca o chão de sob nossos pés, sem fornecer outra base em que nos postemos. (p. 317-318, grifos meus).

Evidencia-se, nas palavras de Hanna Arendt, a dificuldade de identificar o agressor, e acrescentamos, em especial, quando se trata da violência simbólica da ideologia da indústria cultural, porque ela está inconscientemente internalizada. É por aí que as mentiras da indústria cultural tornam-se uma poderosa estratégia de manipulação. Como os indivíduos a acolhem, sob o impacto das leis do inconsciente, passam a agir sob o signo da onipotência $x$ impotência, onipresença $x$ ausência, onisciência $\mathrm{x}$ ignorância. Inexistem leis culturais (ordem social) protetoras que possibilitem o compartilhar de trocas desejantes, afetivas, cognitivas entre os indivíduos. A subjetividade fica à matroca do pânico com as perdas dos referenciais de realidade e de anteparo de autoridade de um outro diferente que possam marcar a separação entre a verdade e a mentira, do possível e do impossível, do amigo e do inimigo. Enfim, certa forma de estado confusional acompanha o dia-a-dia dos homens, vulnerabilizados pela violência internalizada e pela gestão do sentimento de culpabilidade inconsciente (Freud, 1930/ 1981a) que os corrói, sob um nebuloso mundo interno e sob o caos assustador do mundo externo. $\mathrm{O}$ instinto de morte reina soberano quando os indivíduos se transformam em "máscaras mortuárias" e em "pseudo-indivíduos" (Adorno \& Horkheimer, 1986) ou no homem vazio da atualidade pela saturação dos prazeres consumistas hoje disponíveis (Lipovetsky, 1983).

Quando a indignação humana será acionada para reverter todo esse processo de deteriorização do homem? Quando a vitalidade do amor e da possibilidade de o ho- 
mem apreender a verdade que lhe permita preservar a vida, quer seja no plano individual quer nas relações sociais, poderá prevalecer sobre a ostentação prepotente de Tânatos que o arrasta para a cumplicidade com a gerência capitalista da produção da "não-vida" na sociedade? (Polo, 2004).

Ouçamos o apelo à resistência na carta dirigida por Fidel Castro ao senhor Bush, em nome do povo cubano (citado em Marcha Socialista, 2004):

Tudo que se escreve sobre direitos humanos em seu mundo e no de seus aliados que compartilham o saque do planeta, é uma colossal mentira. Milhares de milhões de seres humanos vivem com fome, sem alimentos suficientes, medicinas, roupas, sapatos, casas, em condições subhumanas, sem os mínimos conhecimentos e suficiente informação para compreender sua tragédia e do mundo que vivem.

\section{A esperança de construção de um outro homem}

A saída transformadora dessa barbárie e do caos na cultura só existirá se pudermos resistir e sustentar a esperança utópica de construção de uma cultura feita pelos homens, fundada em laços de solidariedade e amor entre eles e sob a qual seja possível o império da verdade no atendimento às reais necessidades humanas, na produção de uma vida feliz. Mais animador, ainda, embora paradoxalmente sob o risco da própria vida, como observa Hannah Arendt (2002):

Onde todos mentem a cerca de tudo que é importante, aquele que conta a verdade começou a agir; quer o saiba ou não, ele se comprometeu também com os negócios políticos, pois, na improvável eventualidade de que sobreviva, terá dado um primeiro passo para a transformação do mundo. (p. 310-311).

Ainda vale a pena desenvolver a esperança e nos enebriarmos com o hino do indivíduo amado pelo coletivo que recebi de Raul Paredes com a dedicatória:

. . . La convivencia humana tan simplemente organizada para bien común en otras culturas mejores que la nuestra... tan testarudamente desperdiciada en la cultura oficial a la que pertenecemos. Pongamos en tela de juicio nuestros mandamientos mentirosos, nuestros valores desvalorizados y nuestros ideales cargados de soberbia y egoísmo.

La Canción de las Personas ${ }^{2}$

Cuando una mujer de cierta tribu de África descubre que está embarazada, se va a la selva con otras mujeres

y juntas rezan y meditan hasta que aparece la 'canción

de la nueva criatura'.
Cuando nace el bebe, la comunidad se junta

$Y$ le cantan su canción.

Luego, cuando el niño comienza su educación,

El pueblo se junta y le cantan su canción.

Cuando se convierte en adulto, la gente se junta

Nuevamente y canta

Cuando llega el momento de su casamiento la persona escucha su canción

Finalmente, cuando su alma está por irse de este mundo,

La familia y los amigos se aproximan y

Al igual en su nacimiento, cantan su canción para acompañarlo en el 'viaje'.

En esta tribu de Africa hay otra ocasión en la cual se canta

La canción

Si en algun momento de su vida la persona comete un crimen

$O$ un acto social aberrante, lo llevan al centro del poblado

Y la gente de la comunidad forma un circulo a su alredor.

Entonces le cantan su canción

La tribu reconece que la corrección de las conductas antisociales no es el castigo;

Es el amor y el afianzamiento de su verdadera identidad

Cuando reconocemos nuestra propria canción Ya no tenemos deseos ni necesidad de perjudicar a nadie.

Tus amigos conecem 'tu canción'.

$Y$ la cantan cuando tu la olvidas.

Aquello que te aman no pueden ser engañados por los

Errores que cometes o las oscuras imágenes que Muestras a los demas

Ellos recuerdan tu belleza cuando te sientes feo;

Tu integridad cuando estás quebrado;

Tu inocencia cuando te sientes culpable

$Y$ tu propósito cuando estás confuso.

Tolba Phanem

\section{Notas}

1. Curvo, D. R. (2003, 08 abr.). Sexta-feira Santa. Este texto é uma homenagem à morte de Jesus (e não à sua ressurreição).

2. Esse poema foi recebido, em 07/02/2006, por e-mail, de Raul 
Paredes Fernandez, no PPS psicoliberacíon A propósito de interculturalidad y filosofía de vida, em http:// es.groups.yahoo.com/group/psicliberacion/

\section{Referências}

Alba Rico, S. (2007). Símbolos y sinestesias: el bombardeo pacificador. Retirado em 28 abr. 2007, de http://www.rebelion.org/ noticia.php?id=50146

Adorno, T. W. (1986). Indústria cultural. In F. Fernandes (Ed.), Theodor W. Adorno: Sociologia: Vol. 54. Grandes Cientistas Sociais (pp. 92-99). São Paulo, SP: Ática

Adorno, T. W., \& Horkheimer, M. (1985). Dialética do esclarecimento: Fragmentos filosóficos. Rio de Janeiro, RJ: Jorge Zahar.

Adorno, T. W. (1995). Educação e emancipação. Rio de Janeiro, RJ: Paz e Terra.

Aidé, M. A. K. (2002). Me engana que eu gosto: A tirania da sedução. Estudos de Psicanálise - CBP, 25, 67-77.

Ali, T. (2003). Bush na Babilônia: A recolonização do Iraque. Rio de Janeiro, RJ: Record.

Arendt, H. (1973). Da violência. In H. Arendt. Crises da República: Debates (pp. 91-156). São Paulo, SP: Perspectiva.

Arendt, H. (2000). Eichmann em Jerusalém: Um relato sobre a banalidade do mal [Eichmann in Jerusalem: A report on the banality of evil] (J. R. Siqueira, Trad.). São Paulo, SP: Companhia das Letras.

Arendt, H. (2002). Verdade e política. In Entre o passado e o futuro [Between Past and Future] (5. ed., pp. 282-325, M. W. B. Almeida, Trad.). São Paulo, SP: Perspectiva.

Arreguy, M. E., \& Garcia, C. A. (2001). A ausência de ciúme: Notas sobre o consumo do amor. Revista Estudos da Psicanálise. Retirado em 14 nov. 2002, de http://www.cprs.com.br/VIFORUM

Barbarini, N. (2001). Trabalho bancário e reestruturação produtiva: Implicações no psiquismo dos trabalhadores. Dissertação de Mestrado não-publicada, Instituto de Psicologia, Universidade Federal do Rio Grande do Sul, Porto Alegre, RS.

Baudrillard, J. (2002, nov.). A violência da globalização. Le Monde Diplomatique. Retirado em 15 fev. 2003, de http:// diplo.uol.com.br/2002-11,a469

Bauman, Z. (1998). Modernidade e holocausto. Rio de Janeiro, RJ: Jorge Zahar.

Bauman, Z. (2004). Amor liquido: Sobre a fragilidade dos laços humanos. Rio de Janeiro, RJ: Jorge Zahar.

Bauman, Z. (2005). Vidas desperdiçadas. Rio de Janeiro, RJ: Jorge Zahar.

Bettelheim, B. (1989). Sobrevivência e outros estudos [Surving and other essays] (M. C. Monteiro, Trad.). Porto Alegre, RS: Artes Médicas.

Caniato, A. M. P (1995). A história negada: Violência e cidadania sob um enfoque psicopolítico. Tese de Doutorado não-publicada, Instituto de Psicologia da Universidade de São Paulo, SP.

Caniato, A. M. P. (1999a). A impunidade na sociedade e no Direito: Implicações psicossociais. Psicologia-UFF, 11(2-3), 9-26.

Caniato, A. M. P. (1999b). A subjetividade na contemporaneidade: Da estandardização dos indivíduos ao personalismo narcísico. In A. F. Silveira (Ed.), Cidadania e participação social (pp. 1329). Porto Alegre, RS: Abrapsosul.

Caniato, A. M. P. (2000). Da violência no ethos cultural autoritário da contemporaneidade e do sofrimento psicossocial. PSI - Revista de Psicologia Social e Institucional, 2(2), 197-215.

Caniato, A. M. P. (no prelo). A banalização da mentira como uma das perversões da sociedade contemporânea e sua internalização como destrutividade psíquica. Psicologia e Sociedade

Caniato, A. M. P., \& Castro, M. (2004, oct.). El sufrimiento psicosocial. Subjetividad y Cultura, 22, 39-48.

Caniato, A. M. P., Cesnik, C. C., \& Araújo, J. S. (2005). A sustentação subjetiva de práticas psicossociais conformistas. In Anais do IV Encontro Latino-Americano dos Estados Gerais da Psicanálise. Retirado em 20 fev. 2006, de http:// www.estadosgerais.org/encontro/IV/PT/trabalhos/ Angela_Caniato_e_Juliana_Araujo_e_Claudia_Cesnik.pdf

Caniato, A. M. P., \& Nascimento, M. L. (no prelo). A vigilância na contemporaneidade: Seus significados e implicações na subjetividade. Revista de Psicologia da PUC/Minas.

Chaui, M. (1993). Conformismo e resistência. São Paulo, SP: Brasiliense.

Chomsky, N. (2002). 11 de setembro. Rio de Janeiro, RJ: Bertrand Brasil.

Coimbra, C. (2001) Operação Rio: O mito das classes perigosas. Um estudo sobre a violência urbana, a mídia impressa e os discursos de segurança pública. Niterói, RJ: Intertexto.

Coimbra, C. (2003). Gênero, militância e tortura. Retirado em 10 abr. 2007, de http://estadosgerais.org/mundial_rj/port/trabalhos/ 5_Coimbra_136161003_port.htm

Costa, J. F. (1986). Violência e psicanálise. Rio de Janeiro, RJ: Graal.

Debord, G. (1997). A sociedade do espetáculo. Rio de Janeiro, RJ: Contraponto.

Dejours, C. (2000). A banalização da injustiça social. Rio de Janeiro, RJ: Editora da Fundação Getúlio Vargas.

Dufour, D. R. (2001, fev.). As angústias do indivíduo-sujeito. Le Monde Diplomatique - Diplo, 2(13). Retirado em 10 maio 2001, de http:// www.diplo.com.br.

Forrester, V. (1997). O horror econômico. São Paulo, SP: Editora da Universidade do Estado de São Paulo.

Freud, S. (1948a). La angustia. In S. Freud: Vol. 2. Obras Completas (pp. 261-272). Madrid, España: Biblioteca Nueva. (Original publicado em 1916-1918)

Freud, S. (1948b). Metapsicologia. In S. Freud: Vol. 1. Obras Completas (pp. 1023-1074). Madrid, España: Biblioteca Nueva. (Original publicado em 1913-1917)

Freud, S. (1948c). El yo y el ello. In S. Freud: Vol. 2. Obras Completas (pp. 1191-1212). Madrid, España: Biblioteca Nueva. (Original publicado em 1923)

Freud, S. (1981a). El malestar en la cultura. In S. Freud: Vol. 3. Obras Completas (pp. 3018-3067). Madrid, España: Biblioteca Nueva. (Original publicado em 1930)

Freud, S. (1981b). Lo siniestro: In S. Freud: Vol. 3. Obras Completas (pp. 2483-2505). Madrid, España: Biblioteca Nueva. (Original publicado em 1919)

Glassner, B. (2003). A cultura do medo. São Paulo, SP: Francis.

Green, A. (1988). Narcisismo de vida e narcisismo de morte. São Paulo, SP: Escuta.

Ianni, O. (1979). Imperialismo e cultura: Vol. 5. Sociologia Brasileira (3. ed.). Petrópolis, RJ: Vozes.

Ianni, O. (1981). A ditadura do grande capital. Vol. 155. Retratos do Brasil. Rio de Janeiro, RJ: Civilização Brasileira.

Leontiév, A. (1978). O homem e a cultura. In A. Leontiév. O desenvolvimento do psiquismo. Lisboa, Portugal: Horizonte Universitária.

Lipovetsky, G. A. A. (1983). A era do vazio: Ensaio sobre o individualismo contemporâneo. Lisboa, Portugal: Relógio D’Água.

Lowen, A. (1983). Narcisismo: Negação do verdadeiro"self". Rio de Janeiro, RJ: Circulo do Livro. 
Lucchesi, I. (2002, ago.). Mídia e sedução sem encantamento. Observatório da Imprensa. Retirado em 04 set. 2002, de http:// observatoriodaimprensa.com.br/artigosjd060320024.htm

Maci, G. (2005). El poder imaginário del narcisismo. Retirado em 18 fev. 2006, de http://www.institutoarendt.co.ar/conferencias/ Desayuno.Maci.abril2005.pdf

Marcha Socialista. (2004, maio). 'Salve, César, os que vão morrer te saúdam', diz Fidel. Diário Vermelho. Retirado em 22 maio 2004, de http://www.vermelho.org.br/diario/2004/0515/ 0515_fidel-proclamacao.asp

Mariotti, H. (2002). A era da avareza: A concentração de renda como patologia bio-psico-social. Retirado em 20 out. 2004, de http://www.geocities.com/pluriversu/avareza.html.

Martín-Baró, I. (1987). El latino indolente: carácter ideológico del fatalismo latinoamericano: In M. Montero (Ed.), Psicologia Política Latinoamericana (pp. 135-162). Caracas, Venezuela: Panapo.

Martin, H. P., \& Schumann, H. (1999). Armadilha da globalização: $O$ assalto à democracia e ao bem estar social. São Paulo, SP: Globo.

Martorell, F. (1999). Operación Cóndor. El vuelo de la muerte - La Coordinación represiva en el Cono Sur: Septiembre. Santiago de Chile, Chile: LOM Ediciones.

Neiva, P. (2006, 22 fev.). Pacto de morte via internet. Revista Veja, 39(7).

Odália, N. (1983). O que é violência: Vol. 85. Primeiros Passos. São Paulo: Brasiliense.

Polo, H. (2004, 12 abr.). Estados Unidos, sibildos de serpiente. Correio de Información ATTAC, "El Grano de Arena", 235. Retirado em 14 abr. 2004, de http://attac.org/attaccinfoes/ attacinfo235.zip

Primo Levi (2004). Os afogados e os sobreviventes [Sommersi e i Salvati] (2. ed., L. S. Henriques, Trad.). São Paulo, SP: Paz e Terra

Racanello, J. H. B. (1985). O sistema de penas no Brasil. Dissertação de Mestrado não-publicada, Universidade Estadual de Londrina, PR.

Ramonet, I. (2003). Morrer de trabalho. Retirado em 14 abr. 2007, de http://diplo.uol.com.br/imprima666

Rede de Informatica de Instituciones de Derechos Humanos de Chile. (1991). Glosario de definiciones operacionales de las violaciones a los derechos humanos: documentos. Santiago do Chile, Chile: Autor.

Richard, L. (2007). Guernica, agonia de uma guerra. Retirado em 13 abr. 2007, de http://diplo.uol.com.br/2007-04,a1541

Riquelme, H. (1990). Era de Nieblas- derechos humanos, terrorismo de estado y salud psicosocial en America Latina. Caracas, Venezuela: Nueva Sociedad.

Sader, E. (2006, fev./mar.). Civilização ou barbárie? Instituto de Cultura Árabe, Correio do Icarabe, 2(39).

Sennett, R. (2001). Corrosão do caráter - Conseqüências pessoais do trabalho no novo capitalismo. Rio de Janeiro, RJ: Record.

Sodré, M. (2002). Antropológica do espelho: Uma teoria da comunicação linear e em rede. Petrópolis, RJ: Vozes.

Ugalde, A., \& Zwy, A. (1991). El impacto de la violencia del Estado en la salud. Austin, TX: University of Texas. (Mimeo).

Ulloa, F. O. (1999). Sociedad y crueldad (notas preliminares). Les Etats Généraux de la Psychanalyse. Retirado em 21 set. 2002, http://www.etatsgeneraux-psychanalyse.net/archives/ texte171.html

Ulloa, F. O. (2000). Una perspectiva psicoanalitica de la crueldad. In I Encontro Mundial dos Estados Gerais da Psicanálise. Re- tirado em 20 fev. 2006, de http://www.etatsgenerauxpsychanalyse.net/mag/archives/paris2000/texte90.html.

Velho, G. (1997). Individualismo e cultura: Notas para uma antropologia da sociedade contemporânea. Rio de Janeiro, RJ: Jorge Zahar.

Viñar, M., \& Viñar, M. (1992). Exílio e tortura: Sexto Lobo. São Paulo, SP: Escuta.

Ângela Maria Pires Caniato é Professora Doutora do Curso de Mestrado em Psicologia do Departamento de Psicologia da Universidade Estadual de Maringá (UEM) e Psicóloga Clínica. Endereço para correspondência: Rua Joaquim Nabuco, 1496, Zona 04, Maringá, PR, 87 014-100. ampicani@onda.com.br

Violências e Subjetividades: O Indivíduo Contemporâneo Angela Maria Pires Caniato

Recebido: 02/01/2007

$1^{\text {a }}$ revisão: 23/05/2007

Aceite final: 20/6/2007 